\title{
Primary Central Nervous System Lymphoma of the Cerebellopontine Angle: Epidemiological Characteristics and Imaging Features May Be Helpful for Making an Accurate Preoperative Diagnosis
}

\section{Jian Zheng}

Department of Neurosurgery, The Second Affiliated Hospital, Zhejiang University School of Medicine

\section{Buyi Zhang}

Department of Pathology, The Second Affiliated Hospital『Zhejiang University School of Medicine

\section{Zhaoxu Huang}

Department of Echocardiography, The Second Affiliated Hospital, Zhejiang University School of Medicine

Hui Ling

Department of Neurosurgery, The Second Affiliated Hospital, Zhejiang University School of Medicine

\section{Zhangqi Dou}

Department of Neurosurgery, The Second Affiliated Hospital, Zhejiang University School of Medicine Jiawei Wu

Department of Neurosurgery, The Second Affiliated Hospital, Zhejiang University School of Medicine

Taian Jin

Department of Neurosurgery, The Second Affiliated Hospital, Zhejiang University School of Medicine

\section{Danchan Lu}

Rehabilitation \&amp; Sports Medicine Research Institure of Zhejiang Province,Zhejiang Provincial People's Hospital, People's Hospital of Hangzhou Medical College

Chongran Sun ( $\sim$ sun.chongran@zju.edu.cn )

The Second Affiliated Hospital, Zhejiang University School of Medicine https://orcid.org/0000-0001-8070-7492

\section{Research Article}

Keywords: Primary central nervous system lymphoma, Cerebellopontine angle, T1-weighted image, T2-weighted image, Magnetic resonance imaging.

Posted Date: March 30th, 2021

DOI: https://doi.org/10.21203/rs.3.rs-345358/v1

License: (c) (i) This work is licensed under a Creative Commons Attribution 4.0 International License. Read Full License 


\section{Abstract}

\section{Purpose}

Primary central nervous system lymphoma (PCNSL) of the cerebellopontine angle (CPA) is rare, thus the preoperative diagnosis is still a challenge.

\section{Methods}

We searched the database at our institution and performed a search of English literature in PubMed and Google Scholar. Keywords used were as follows: "primary central nervous system lymphoma"; "cerebellopontine angle"; "lymphoma". Only cases in the English language that were located in the CPA and contained adequate clinical information pertinent to the analysis were included.

\section{Results}

297 cases of pathologically confirmed PCNSLs were recorded between January 2009 and October 2020 at our institution. 6 cases were located in the CPA, accounting for $2.0 \%$ of all PCNSLs. 26 cases meeting the above criteria were found in the literature. Including ours, a total of 32 patients were analyzed. Females were more frequently affected (F/M ratio, 2.2:1). There was a preponderance of left-sided lesions in the PCNSLs of the CPA (L/R ratio, 1.5:1). On CT, 80.0\% of them presented as hyperdense lesions. On T1-weighted image, $66.7 \%$ appeared isointense. While on T2-weighted image (T2WI), 68.4\% appeared isointense/hypointense. After contrast administration, $86.2 \%$ presented intense homogeneous enhancement.

\section{Conclusion}

PCNSL of the CPA is extremely rare, accounting for $2.0 \%$ of all PCNSLs in our study. There is a preponderance of females and left-sided lesions in this disease. Contrast-enhanced magnetic resonance imaging with $\mathrm{T} 2 \mathrm{Wl}$ is very helpful in the preoperative diagnosis of the CPA PCNSL. Although rare, lymphoma should be included in the differential diagnosis of CPA lesions.

\section{Introduction}

Primary central nervous system lymphoma (PCNSL) is a rare malignant extranodal non-Hodgkin's lymphoma that arises in the craniospinal axis [1, 2]. Most PCNSLs are supratentorial in a central location, including the corpus callosum, basal ganglia, thalamus, and paraventricular region [3-5]. Infratentorial PCNSL is rare, accounting for only $10 \%-20 \%$ of all PCNSLs [6]. PCNSL of the cerebellopontine angle (CPA) is extremely rare and would probably be mistaken for other CPA lesions such as vestibular schwannomas or meningiomas [4-6]. To the best of our knowledge, only 26 cases of CPA PCNSLs have been previously reported in the English literature [3-28]. We present six new cases of CPA PCNSLs and discuss the presentation, radiologic characteristics, preoperative differential diagnosis and treatment.

\section{Materials And Methods}

The neurosurgical database at the Second Affiliated Hospital of Zhejiang University School of Medicine, was searched for all surgical cases of primary central nervous system lymphomas between January 2009 and October 2020. A retrospective chart review was then performed with research ethics board approval. The age, sex, image 
presentation, location, preoperative diagnosis, surgical management and pathological examination were recorded. All patients underwent computed tomography (CT) or magnetic resonance imaging (MRI) for diagnosis and surgical planning. Postoperative clinical information and neuroradiological presentation were evaluated.

Additionally, for the review, a search was conducted of the English literature in PubMed and Google Scholar for every case report, series, letter to the editor, original article and literature review related to PCNSL of the CPA. In addition, the reference lists of the obtained articles and previous reviews were examined. Keywords used were as follows (single word or combination): "primary central nervous system lymphoma"; "cerebellopontine angle"; "Iymphoma". Only cases in the English language that were located in the CPA and contained adequate clinical information pertinent to the analysis were included.

\section{Results}

Two hundred and ninety-seven cases of pathologically confirmed primary central nervous system lymphoma were recorded between January 2009 and October 2020 at our institution. Six of them were located in the CPA, accounting for $2.0 \%$ of all PCNSLs in the present study. They comprised two men and four women with an average age of 60.8 years (range 51-69 years). Headache and vomiting were the most common presenting symptoms, and were seen in four cases. Other symptoms and signs included hearing loss, dizziness, dysphagia, hoarseness, facial palsy and facial hypoesthesia. PCNSL of the CPA was frequently found on the left than on the right side (L/R ratio, 2:1). In two patients, tumors were resected via suboccipital retrosigmoid craniotomy. In the other four patients, stereotactic biopsy was performed.

The English medical literature in the PubMed and Google Scholar databases was reviewed, and 26 cases of CPA PCNSLs meeting the above-mentioned criteria were included. The characteristics of the 26 cases were summarized in Table 1. Including our six patients, a total of 32 cases were analyzed. The reported age range was between 21 and 82 years, with a median age of 56.5 years. Females were more frequently affected (F/M ratio, 2.2:1). Regarding the locations of PCNSLs of the CPA, 18 cases (56.3\%) were in the left side, 12 cases (37.5\%) were in right side, and 2 cases (6.3\%) were bilateral. The most frequent initial symptom of CPA PCNSL was hearing disturbance (64.5\% of all the patients), and cerebellar signs (ataxia and unsteady gait) were the second most common symptom ( $41.9 \%$ of all the patients). Facial palsy, headache and vomiting were also common symptoms. CT examinations were performed in 15 cases, $80.0 \%$ presented as hyperdense lesions ( 12 cases), $13.3 \%$ appeared as isodense masses ( 2 cases), and only $6.7 \%$ showed hypodense masses ( 1 cases). Contrast-enhanced CT examination were performed in 6 cases, and all appeared significant enhancement. On T1-weighted image (T1WI), $66.7 \%$ appeared isointense and $33.3 \%$ presented hypointense. While on T2-weighted image (T2WI), $42.1 \%$ appeared isointense, $31.6 \%$ presented hyperintense and $26.3 \%$ showed hypointense. After contrast administration, $86.2 \%$ presented an intense homogeneous enhancement, $10.3 \%$ showed a heterogeneous enhancement, and only $3.4 \%$ appeared no enhancement. Craniotomy for tumor resection was performed in $80.6 \%$ of the patients (25 cases), and stereotactic biopsy was achieved in $12.9 \%$ of the patients (4 cases, all in the present study).

Cerebrospinal fluid (CSF) cytology was used to diagnose pathologically in one patient. One patient was diagnosed at autopsy. Most of the preoperative diagnoses were schwannoma and meningioma, other preoperative diagnoses included metastatic tumor, hemagioma and tuberculosis meningitis. Only three cases were accurately diagnosed preoperatively. Diffuse large B-cell lymphoma was the most common type of PCNSLs of the CPA. 
Table 1

Reported cases of primary central nervous system lymphoma of the cerebellopontine angle

\begin{tabular}{|c|c|c|c|c|c|c|c|}
\hline Case & $\begin{array}{l}\text { Authors/ } \\
\text { Reference }\end{array}$ & Age/sex & Side & $\begin{array}{l}\text { Clinical } \\
\text { presentation }\end{array}$ & $\begin{array}{l}\text { CT/MRI } \\
\text { Characteristics }\end{array}$ & $\begin{array}{l}\text { Preoperative } \\
\text { diagnosis }\end{array}$ & Surgery \\
\hline 1 & Yan et al. [7] & $43 \mathrm{y} / \mathrm{F}$ & $L$ & $\begin{array}{l}\text { Hearing loss, } \\
\text { headache, } \\
\text { vomiting }\end{array}$ & $\begin{array}{l}\text { MRI: } \\
\text { isointense on } \\
\text { T2 and T1, } \\
\text { homogeneous } \\
\text { enhancement }\end{array}$ & Schwannoma & Craniotomy \\
\hline 2 & $\begin{array}{l}\text { Danchaivijitr } \\
\text { et al. [8] }\end{array}$ & $21 \mathrm{y} / \mathrm{F}$ & $\mathrm{R}$ & $\begin{array}{l}\text { Hearing loss, } \\
\text { facial palsy, } \\
\text { facial } \\
\text { dysesthesias, } \\
\text { headache, } \\
\text { nausea, } \\
\text { vomiting }\end{array}$ & $\begin{array}{l}\text { CT: } \\
\text { hyperdense. } \\
\text { MRI: } \\
\text { hypointense } \\
\text { on T1 and T2, } \\
\text { heterogeneous } \\
\text { enhancement }\end{array}$ & $\begin{array}{l}\text { Meningioma, } \\
\text { schwannoma }\end{array}$ & Craniotomy \\
\hline 3 & $\begin{array}{l}\text { Nishimura et } \\
\text { al. [9] }\end{array}$ & $63 \mathrm{y} / \mathrm{F}$ & $L$ & $\begin{array}{l}\text { Dizziness, } \\
\text { nausea, ataxia, } \\
\text { nystagmus }\end{array}$ & $\begin{array}{l}\text { CT: } \\
\text { hyperdense, } \\
\text { homogeneous } \\
\text { enhancement. } \\
\text { MRI: } \\
\text { hypointense } \\
\text { on T1, } \\
\text { isointense on } \\
\text { T2, no } \\
\text { enhancement }\end{array}$ & $\begin{array}{l}\text { Meningioma, } \\
\text { schwannoma }\end{array}$ & Craniotomy \\
\hline 4 & Hill et al. [10] & 76 y/F & $\mathrm{R}$ & $\begin{array}{l}\text { Hearing loss, } \\
\text { facial palsy, } \\
\text { ataxia }\end{array}$ & $\begin{array}{l}\text { MRI: } \\
\text { homogenous } \\
\text { enhancement }\end{array}$ & N.A. & Craniotomy \\
\hline 5 & $\begin{array}{l}\text { Yang et al. } \\
\text { [11] }\end{array}$ & $50 \mathrm{y} / \mathrm{M}$ & $L$ & $\begin{array}{l}\text { Hearing loss, } \\
\text { ataxia, } \\
\text { dizziness }\end{array}$ & $\begin{array}{l}\text { CT: isodense, } \\
\text { homogeneous } \\
\text { enhancement }\end{array}$ & N.A. & Craniotomy \\
\hline 6 & $\begin{array}{l}\text { Wang et al. } \\
\text { [12] }\end{array}$ & $57 \mathrm{y} / \mathrm{M}$ & $L$ & $\begin{array}{l}\text { Hearing loss, } \\
\text { facial } \\
\text { numbness, } \\
\text { facial palsy, } \\
\text { ataxia }\end{array}$ & $\begin{array}{l}\text { MRI: } \\
\text { isointense on } \\
\text { T1 and T2, } \\
\text { homogeneous } \\
\text { enhancement }\end{array}$ & Schwannoma & Craniotomy \\
\hline 7 & $\begin{array}{l}\text { Bonneville et } \\
\text { al. [13] }\end{array}$ & $49 \mathrm{y} / \mathrm{M}$ & $\mathrm{R}$ & N.A. & $\begin{array}{l}\text { MRI: } \\
\text { homogeneous } \\
\text { enhancement }\end{array}$ & N.A. & N.A. \\
\hline 8 & $\begin{array}{l}\text { Jaiswal et al. } \\
\text { [14] }\end{array}$ & $36 \mathrm{y} / \mathrm{M}$ & B & $\begin{array}{l}\text { Hearing loss, } \\
\text { facial palsy, } \\
\text { tinnitus, } \\
\text { headache, } \\
\text { ataxia, } \\
\text { nystagmus }\end{array}$ & $\begin{array}{l}\text { MRI: } \\
\text { isointense on } \\
\text { T1, } \\
\text { hyperintense } \\
\text { on T2, } \\
\text { homogenous } \\
\text { enhancement }\end{array}$ & N.A. & Craniotomy \\
\hline
\end{tabular}

M, male; F, female; y, year; N.A., not available; L, left; R, right; B, bilateral; MRI, Magnetic Resonance Imaging; T1, T1-weighted imaging; T2, T2-weighted imaging. 


\begin{tabular}{|c|c|c|c|c|c|c|c|}
\hline Case & $\begin{array}{l}\text { Authors/ } \\
\text { Reference }\end{array}$ & Age/sex & Side & $\begin{array}{l}\text { Clinical } \\
\text { presentation }\end{array}$ & $\begin{array}{l}\text { CT/MRI } \\
\text { Characteristics }\end{array}$ & $\begin{array}{l}\text { Preoperative } \\
\text { diagnosis }\end{array}$ & Surgery \\
\hline 9 & $\begin{array}{l}\text { Wen et al. } \\
\text { [15] }\end{array}$ & $75 \mathrm{y} / \mathrm{F}$ & L & $\begin{array}{l}\text { Facial palsy, } \\
\text { facial } \\
\text { hypoesthesia, } \\
\text { dizziness }\end{array}$ & $\begin{array}{l}\text { MRI: } \\
\text { homogenous } \\
\text { enhancement }\end{array}$ & N.A. & Craniotomy \\
\hline 10 & $\begin{array}{l}\text { Garth et al. } \\
\text { [16] }\end{array}$ & $68 \mathrm{y} / \mathrm{F}$ & B & $\begin{array}{l}\text { Hearing loss, } \\
\text { ataxia, } \\
\text { diplopia, } \\
\text { dysarthria, } \\
\text { nystagmus, } \\
\text { reduced } \\
\text { corneal reflexe }\end{array}$ & $\begin{array}{l}\text { CT: } \\
\text { hyperdense. } \\
\text { MRI: } \\
\text { homogenous } \\
\text { enhancement }\end{array}$ & N.A. & Craniotomy \\
\hline 11 & $\begin{array}{l}\text { lerokomos et } \\
\text { al. [17] }\end{array}$ & $82 \mathrm{y} / \mathrm{F}$ & L & Hearing loss & $\begin{array}{l}\text { CT: } \\
\text { hypodense, } \\
\text { enhancement }\end{array}$ & N.A. & Craniotomy \\
\hline 12 & $\begin{array}{l}\text { Itoh et al. } \\
{[18]}\end{array}$ & $28 \mathrm{y} / \mathrm{F}$ & L & $\begin{array}{l}\text { Hearing loss, } \\
\text { tinnitus, } \\
\text { nausea, } \\
\text { vomiting, } \\
\text { nystagmus }\end{array}$ & $\begin{array}{l}\text { MRI: } \\
\text { isointense on } \\
\text { T1, slight } \\
\text { hyperintense } \\
\text { on T2, } \\
\text { homogenous } \\
\text { enhancement }\end{array}$ & Schwannoma & Craniotomy \\
\hline 13 & $\begin{array}{l}\text { Berciano et } \\
\text { al. [19] }\end{array}$ & $39 \mathrm{y} / \mathrm{F}$ & L & $\begin{array}{l}\text { Hearing loss, } \\
\text { facial } \\
\text { paraesthesiae, } \\
\text { headache, } \\
\text { vomiting, } \\
\text { otalgia }\end{array}$ & $\begin{array}{l}\text { CT: } \\
\text { hyperdense, } \\
\text { enhancement }\end{array}$ & N.A. & Autopsy \\
\hline 14 & $\begin{array}{l}\text { Angeli et al. } \\
{[20]}\end{array}$ & $56 \mathrm{y} / \mathrm{F}$ & L & $\begin{array}{l}\text { Hearing loss, } \\
\text { facial palsy, } \\
\text { ataxia }\end{array}$ & $\begin{array}{l}\text { MRI: isodense } \\
\text { on TI, } \\
\text { homogenous } \\
\text { enhancement }\end{array}$ & $\begin{array}{l}\text { Schwannoma, } \\
\text { hemangioma }\end{array}$ & Craniotomy \\
\hline 15 & $\begin{array}{l}\text { Kariya et al. } \\
{[21]}\end{array}$ & $63 \mathrm{y} / \mathrm{M}$ & $\mathrm{R}$ & $\begin{array}{l}\text { Hearing loss, } \\
\text { tinnitus, } \\
\text { ataxia, } \\
\text { dizziness, } \\
\text { nausea }\end{array}$ & $\begin{array}{l}\text { CT: } \\
\text { enhancement. } \\
\text { MRl: } \\
\text { heterogeneous } \\
\text { enhancement }\end{array}$ & N.A. & Craniotomy \\
\hline 16 & $\begin{array}{l}\text { Taskin et al. } \\
\text { [22] }\end{array}$ & $43 \mathrm{y} / \mathrm{F}$ & $\mathrm{R}$ & $\begin{array}{l}\text { Hearing loss, } \\
\text { facial palsy, } \\
\text { dizziness, } \\
\text { ataxia }\end{array}$ & $\begin{array}{l}\text { CT: } \\
\text { enhancement. } \\
\text { MRI: } \\
\text { homogenous } \\
\text { enhancement }\end{array}$ & N.A. & Craniotomy \\
\hline 17 & $\begin{array}{l}\text { Shuangshoti } \\
\text { [23] }\end{array}$ & $27 \mathrm{y} / \mathrm{F}$ & $\mathrm{R}$ & $\begin{array}{l}\text { Hearing loss, } \\
\text { facial palsy, } \\
\text { ataxia; corneal } \\
\text { reflex } \\
\text { decreased; } \\
\text { hoarseness }\end{array}$ & $\begin{array}{l}\text { CT: } \\
\text { enhancement. } \\
\text { MRI: isodense } \\
\text { on T1, } \\
\text { homogenous } \\
\text { enhancement }\end{array}$ & N.A. & Craniotomy \\
\hline
\end{tabular}

M, male; F, female; $y$, year; N.A., not available; L, left; R, right; $B$, bilateral; MRI, Magnetic Resonance Imaging; T1, T1-weighted imaging; T2, T2-weighted imaging. 


\begin{tabular}{|c|c|c|c|c|c|c|c|}
\hline Case & $\begin{array}{l}\text { Authors/ } \\
\text { Reference }\end{array}$ & Age/sex & Side & $\begin{array}{l}\text { Clinical } \\
\text { presentation }\end{array}$ & $\begin{array}{l}\text { CT/MRI } \\
\text { Characteristics }\end{array}$ & $\begin{array}{l}\text { Preoperative } \\
\text { diagnosis }\end{array}$ & Surgery \\
\hline 18 & $\begin{array}{l}\text { Seevaratnam } \\
\text { et al. [24] }\end{array}$ & $60 y / F$ & L & $\begin{array}{l}\text { Hearing loss, } \\
\text { headache, } \\
\text { vomiting, } \\
\text { ataxia }\end{array}$ & $\begin{array}{l}\text { CT: } \\
\text { hyperdense. } \\
\text { MRI: } \\
\text { isointense on } \\
\text { T1, } \\
\text { hypointense } \\
\text { on T2, } \\
\text { homogeneous } \\
\text { enhancement }\end{array}$ & Schwannoma & Craniotomy \\
\hline 19 & $\begin{array}{l}\text { Phang et al. } \\
\text { [25] }\end{array}$ & $48 y / F$ & $\mathrm{R}$ & $\begin{array}{l}\text { Facial pain, } \\
\text { unsteadiness, } \\
\text { facial } \\
\text { hypoesthesia, } \\
\text { corneal reflex } \\
\text { decreased }\end{array}$ & $\begin{array}{l}\text { MRI: } \\
\text { hypointense } \\
\text { on T2, } \\
\text { homogeneous } \\
\text { enhancement }\end{array}$ & $\begin{array}{l}\text { Schwannoma, } \\
\text { meningioma }\end{array}$ & Craniotomy \\
\hline 20 & $\begin{array}{l}\text { Cederberg et } \\
\text { al. [26] }\end{array}$ & $48 y / F$ & L & $\begin{array}{l}\text { Headache, } \\
\text { facial palsy, } \\
\text { facial } \\
\text { hypoaesthesia }\end{array}$ & $\begin{array}{l}\text { MRI: } \\
\text { homogeneous } \\
\text { enhancement }\end{array}$ & $\begin{array}{l}\text { Tuberculosis } \\
\text { meningitis }\end{array}$ & $\begin{array}{l}\text { CSF } \\
\text { cytology }\end{array}$ \\
\hline 21 & $\begin{array}{l}\text { Berrocal et } \\
\text { al. [6] }\end{array}$ & $60 y / M$ & L & $\begin{array}{l}\text { Hearing loss, } \\
\text { facial } \\
\text { hypoaesthesia, } \\
\text { ataxia }\end{array}$ & $\begin{array}{l}\text { MRI: } \\
\text { hypointense } \\
\text { on T1, } \\
\text { moderately } \\
\text { hyperintense } \\
\text { on T2, } \\
\text { homogeneous } \\
\text { enhancement }\end{array}$ & $\begin{array}{l}\text { Schwannoma, } \\
\text { meningioma, }\end{array}$ & Craniotomy \\
\hline 22 & Shin et al. [4] & $47 y / F$ & $\mathrm{R}$ & Facial palsy & $\begin{array}{l}\text { CT: slightly } \\
\text { hyperdense, } \\
\text { homogeneous } \\
\text { enhancement } \\
\text { MRI: } \\
\text { hypointense } \\
\text { on T1, } \\
\text { isointense on } \\
\text { T2, } \\
\text { homogeneous } \\
\text { enhancement }\end{array}$ & $\begin{array}{l}\text { Meningioma, } \\
\text { Schwannoma }\end{array}$ & Craniotomy \\
\hline 23 & $\begin{array}{l}\text { Mori et al. } \\
\text { [27] }\end{array}$ & $50 y / M$ & $\mathrm{R}$ & $\begin{array}{l}\text { Dizziness, } \\
\text { hearing loss }\end{array}$ & $\begin{array}{l}\text { MRI: } \\
\text { homogeneous } \\
\text { enhancement }\end{array}$ & N.A. & Craniotomy \\
\hline 24 & Lin et al. [3] & $67 y / F$ & $\mathrm{R}$ & $\begin{array}{l}\text { Dysphagia, } \\
\text { dizziness }\end{array}$ & $\begin{array}{l}\text { MRI: slightly } \\
\text { hypointense } \\
\text { on T1, slightly } \\
\text { hypointense } \\
\text { on T2, } \\
\text { homogeneous } \\
\text { enhancement }\end{array}$ & Metastasis & Craniotomy \\
\hline
\end{tabular}

$M$, male; F, female; y, year; N.A., not available; L, left; $R$, right; $B$, bilateral; MRI, Magnetic Resonance Imaging; T1, T1-weighted imaging; T2, T2-weighted imaging. 


\begin{tabular}{|c|c|c|c|c|c|c|c|}
\hline Case & $\begin{array}{l}\text { Authors/ } \\
\text { Reference }\end{array}$ & Age/sex & Side & $\begin{array}{l}\text { Clinical } \\
\text { presentation }\end{array}$ & $\begin{array}{l}\text { CT/MRI } \\
\text { Characteristics }\end{array}$ & $\begin{array}{l}\text { Preoperative } \\
\text { diagnosis }\end{array}$ & Surgery \\
\hline 25 & $\begin{array}{l}\text { Mielczarek et } \\
\text { al. [28] }\end{array}$ & $65 y / F$ & L & $\begin{array}{l}\text { Hearing loss, } \\
\text { tinnitus, } \\
\text { vertigo, facial } \\
\text { palsy }\end{array}$ & $\begin{array}{l}\text { MRI: } \\
\text { isointense on } \\
\text { T1, } \\
\text { hypointense } \\
\text { on T2, } \\
\text { homogeneous } \\
\text { enhancement }\end{array}$ & Schwannoma & Craniotomy \\
\hline 26 & $\begin{array}{l}\text { Kommu et al. } \\
{[5]}\end{array}$ & $24 y / M$ & L & $\begin{array}{l}\text { Headache, } \\
\text { vomiting }\end{array}$ & $\begin{array}{l}\text { CT: slightly } \\
\text { hyperdense. } \\
\text { MRI: } \\
\text { isointense on } \\
\text { T1 and T2, } \\
\text { heterogeneous } \\
\text { enhancement }\end{array}$ & Schwannoma & Craniotomy \\
\hline
\end{tabular}

\section{Illustrate Case Presentation}

A 63-year-old man presented with left sided hearing loss for 3 months, and continuous headache accompanied by nausea and vomiting for 1 month. His past medical history was unremarkable. On admission, he was alert and cooperative. Visual fields and acuity were normal. Complete physical examination revealed no lymphadenopathy or organomegaly. Neurological examinations revealed left facial palsy (House-Brackmann Grade 4) and moderate degree of hearing loss on the left side. The rest of the neurological and general examinations was unremarkable. Routine hematological parameters including tumour markers were within normal limits, and the serology tests for $\mathrm{HBV}, \mathrm{HCV}$, and HIV were negative.

CT scan revealed a slight hyperdense mass in the left CPA (Fig. 1). No adjacent bony abnormality was present. The lesion was isointense on T1WI and T2WI (Fig. 2a, b). The fourth ventricle and adjacent brainstem were mildly compressed by the lesion. Perifocal edema was detected on the T2WI (Fig. 2b). Contrast-enhanced MRI demonstrated a well-enhanced mass lesion in the left CPA, extending into the left internal auditory canal (Fig. 2ce). FDG-PET/CT examination showed an intensely hypermetabolic lesion in the left CPA (Fig. 3), thus excluding the possibility with systemic tumor. Lumbar puncture was performed, CSF analysis revealed an increased protein level (protein $321.8 \mathrm{mg} / \mathrm{dL}$ ), with a normal glucose level and a pleocytosis with a preponderance of lymphocytes (98\% lymphocytes). Additionally, CSF IgG was significantly elevated (377.0 mg/L). No bacteria, acid-fast bacilli, or fungal organisms were seen on smears or cultures. CSF cytology revealed no malignant cells. On the basis of these imaging findings, a malignant pathology such as high-grade glioma, metastatic tumor or lymphoma were considered preoperatively. We recommended craniotomy or stereotactic biopsy with pathological examination. Finally, the patient and his family chose stereotactic biopsy. No steroid treatment before the surgery was provided.

Stereotactic biopsy was carried out to obtain tumor tissue. The frozen section was suggestive of a lymphoma. Haematoxylin and eosin (H\&E) staining showed diffuse infiltration of large anaplastic cells with irregular nuclei and scanty cytoplasm, with frequent mitoses and apoptosis (Fig. 4a). The immunohistochemical study yielded positive results for $C D 20$ and $C D 79 a$, and negative results for $C D 3, C D 43$ and glial fibrillary acidic protein (GFAP) 
(Fig. 4b). These findings were compatible with primary diffuse large B-cell lymphoma (DLBCL) of the central nervous system.

Postoperatively, the patient's hearing loss and facial palsy were unchanged and no additional neurological deficits were developed. He was then transferred to the hematology department for chemotherapy.

\section{Discussion}

Primary central nervous system lymphoma is a rare and aggressive extranodal non-Hodgkin lymphoma that restricted entirely to the brain, leptomeninges, spinal cord or eyes, without systemic involvement $[9,29]$. PCNSL accounts for approximately $1-4 \%$ of all primary brain tumors $[2,24]$, but its incidence has been increasing over the past 20 years in both immunocompetent and immunocompromised individuals [10, 12]. Diffuse large B-Cell Lymphomas are the most common type ( 90\%), while the remaining 10\% are poorly characterized by Burkitt's lymphomas, T-Cell lymphomas and low-grade lymphomas [29-32]. PCNSL most commonly locates in the cerebral hemispheres (38\%), thalami/basal ganglia (16\%), corpus callosum (14\%), periventricular region (12\%), or cerebellum $(9 \%)[3,5]$, while it rarely occurs in the CPA. We reviewed 32 cases of PCNSLs of the CPA, including the reported cases in the English literature and six patients in our hospital, trying to figure out the accurate preoperative diagnosis of this rare disease.

The incidence of PCNSL of the CPA has never been previously reported in the literature. In the present study, we found that PCNSL of the CPA accounts for $2 \%$ of all PCNSLs. In contrast to those with PCNSLs (M/F ratio, 2:1) [8, 33], there was a preponderance of females in those with PCNSLs of the CPA (M/F ratio, 1:2.2) according to our study. With regard to the laterality of the lesions, there was a preponderance of left-sided lesions in the PCNSLs of the CPA (L/R ratio, 1.5:1). Clinical manifestations of the PCNSLs of the CPA are related to the anatomical structures surrounding the lesion and volumes of the tumors. PCNSLs of the CPA typically present with trigeminal, facial, audiovestibular and cerebellar dysfunction, including hearing loss, tinnitus, facial palsy, vertigo and ataxia $[7,10,14,29]$. Other neurological symptoms include headache, nausea, vomiting, hoarseness and nystagmus [18, $23,24]$.

Given that CPA PCNSLs can be very non-specific with the presenting symptoms, accurate preoperative diagnosis of the lesion is mainly based upon imaging. On computed tomography (CT) scan, PCNSLs of the CPA generally present as hyperdense lesions with homogenous enhancement after contrast administration [9, 21, 24, 30]. Bony erosion and expansion of the internal auditory canal is rare in the PCNSL of CPA, which can be differentiate from acoustic neurinoma [9]. In the present study, we found that $80.0 \%$ of all the CPA PCNSLs presented as hyperdense lesions on CT scans. On MRI, PCNSLs of the CPA are typically homogeneously isointense on T1WI [7, 12, 14], and homogeneously isointense/hypointense with mild perifocal edema on T2WI [8, 9, 24]. After contrast administration, they show an intense homogeneous enhancement [21,34]. In a review of the MRI appearance of CPA PCNSLs in the present study, 66.7\% appeared isointense on T1WI, and 68.4\% appeared isointense/hypointense on T2WI. After contrast administration, $86.2 \%$ presented an intense homogeneous enhancement.

Accurate preoperative diagnosis of CPA PCNSLs can be very difficult due to the rarity and clinical similarities to other common CPA tumors. However, increasing experience with CT and MRI studies allow greater accuracy in the preoperative differential diagnosis [35]. The common differential diagnosis includes schwannoma (70\%-90\%), meningioma (5\%-10\%), epidermoid cyst (5\%-7\%), metastatic tumors and glomus jugulare tumors $[5,6,8,14,35$, 
36]. Kendall et al analyzed 208 cases of CPA tumours and found bony erosion of the internal auditory canal in 98 cases on CT scan, with $93.9 \%$ of the of these being acoustic neuromas [37]. However, bony erosion and expansion of the internal auditory canal is rarely observed in CPA PCNSLs, which can be differentiate from acoustic neurinomas [9]. Characteristic T2-wighted MRI may play an important role in the preoperative differential diagnosis [7-9]. In the present study, we found that $68.4 \%$ of all the CPA PCNSLs appeared as isointense to hypointense on T2WI, which is in contrast to most other CPA lesions [24,38]. This signal intensity is attributable to the high cellularity and high nuclear to cytoplasmic ratio of the PCNSL, which also correspondingly explains the high signal intensity of PCNSLs usually observed on diffusion-weighted imaging (DWI) [13, 24]. In our study, we found that only three case were accurately diagnosed preoperatively, and all the three cases were identified at our institution. The accurate preoperative diagnosis is mainly because of the accumulated experience from the previous surgery cases of CPA PCNSLs.

When PCNSL of CPA is suspected by CT/MRI, conclusive diagnosis should be made by histological or cytological examination of tumour [21, 28, 30]. CSF sampling by lumbar puncture can be performed at the time of initial assessment $[21,30]$. If CSF cytology is successful to establish a definitive diagnosis of malignant lymphoma, surgery can be avoided [21, 39]. However, the positive rate of CSF cytology is low. Balmaceda et al. reported that the initial CSF cytological studies were positive in only 15\% [40]. Serial CSF samples may result in increased diagnostic sensitivity [30]. If CSF cytology failed to confirm the diagnosis, tumor excision or biopsy should be performed. The aim of the surgery is to obtain a frozen section of CPA PCNSL during surgery $[14,15]$. Since radical tumor resection has no advantage on survival and may cause more neurologic deficits, radical decompression should be discouraged $[12,14,15]$. It is advisable to proceed with stereotactic biopsy for brain lesions with a radiographic appearance consistent with PCNSL [31]. Once the diagnosis of CPA PCNSL is established, more effective treatment should be delivered. However, the optimal treatment of PCNSL has yet to be defined [31]. High-dose methotrexate (HD-MTX) - based induction chemotherapy is considered standard for newly diagnosed PCNSL [31]. Through review of the literature and our cases (Tables 1,2), CSF cytology was used to diagnose pathologically in only one patient, tumor resection was performed in $80.6 \%$ of the patients, and stereotactic biopsy was achieved in only $13.8 \%$ of the patients. 
Table 2

Primary central nervous system lymphoma of the cerebellopontine angle in the present study

\begin{tabular}{|c|c|c|c|c|c|c|}
\hline Case & Age/sex & Side & $\begin{array}{l}\text { Clinical } \\
\text { presentation }\end{array}$ & CT/MRI Characteristics & $\begin{array}{l}\text { Preoperative } \\
\text { diagnosis }\end{array}$ & Surgery \\
\hline 1 & $61 \mathrm{y} / \mathrm{M}$ & $\mathrm{L}$ & $\begin{array}{l}\text { Hearing loss, } \\
\text { headache, } \\
\text { vomiting }\end{array}$ & $\begin{array}{l}\text { MRI: isointense on T1 and T2, } \\
\text { homogeneous enhancement }\end{array}$ & Meningioma & Craniotomy \\
\hline 2 & $69 \mathrm{y} / \mathrm{F}$ & $\mathrm{R}$ & $\begin{array}{l}\text { Dysphagia, } \\
\text { hoarseness }\end{array}$ & $\begin{array}{l}\text { CT: hyperdense. MRI: } \\
\text { hypointense on T1, isointense } \\
\text { on T2, homogeneous } \\
\text { enhancement }\end{array}$ & Meningioma & Craniotomy \\
\hline 3 & $51 \mathrm{y} / \mathrm{F}$ & $L$ & $\begin{array}{l}\text { Facial } \\
\text { hypoesthesia, } \\
\text { slurred speech }\end{array}$ & $\begin{array}{l}\text { CT: hyperdense. MRI: } \\
\text { isointense on T1, slightly } \\
\text { hyperintense on T2, } \\
\text { homogeneous enhancement }\end{array}$ & Lymphoma & $\begin{array}{l}\text { Stereotactic } \\
\text { biopsy }\end{array}$ \\
\hline 4 & $63 \mathrm{y} / \mathrm{M}$ & $\mathrm{L}$ & $\begin{array}{l}\text { Hearing loss, } \\
\text { headache, } \\
\text { nausea, vomiting, } \\
\text { facial palsy }\end{array}$ & $\begin{array}{l}\text { CT: hyperdense. MRI: } \\
\text { isointense on T1 and T2, } \\
\text { homogeneous enhancement }\end{array}$ & $\begin{array}{l}\text { Malignant } \\
\text { tumor }\end{array}$ & $\begin{array}{l}\text { Stereotactic } \\
\text { biopsy }\end{array}$ \\
\hline 5 & 59 y/F & $\mathrm{R}$ & $\begin{array}{l}\text { Headache, } \\
\text { dizziness, } \\
\text { vomiting }\end{array}$ & $\begin{array}{l}\text { CT: isodense. MRI: isointense } \\
\text { on T1, slightly hyperintense } \\
\text { on T2, homogeneous } \\
\text { enhancement }\end{array}$ & Lymphoma & $\begin{array}{l}\text { Stereotactic } \\
\text { biopsy }\end{array}$ \\
\hline 6 & $62 \mathrm{y} / \mathrm{F}$ & $L$ & $\begin{array}{l}\text { Headache, } \\
\text { vomiting, facial } \\
\text { hypoesthesia }\end{array}$ & $\begin{array}{l}\text { CT: hyperdense. MRI: } \\
\text { hypointense on T1, slightly } \\
\text { hyperintense on T2, } \\
\text { homogeneous enhancement }\end{array}$ & Lymphoma & $\begin{array}{l}\text { Stereotactic } \\
\text { biopsy }\end{array}$ \\
\hline
\end{tabular}

\section{Conclusion}

In conclusion, PCNSL of CPA is extremely rare lesion, accounting for $2.0 \%$ of all PCNSLs in the present study. There is a preponderance of females and left-sided lesions in the PCNSLs of CPA. Contrast-enhanced MRI with T2WI is very helpful in the preoperative diagnosis of the CPA PCNSL. Although rare, lymphoma should be included in the differential diagnosis of CPA lesions.

\section{Declarations}

Funding The work was supported by the grant of the National Nature Science Foundation of China (Grant No. 81701153); and Key Research and Development Projects in Zhejiang Province, China. (No. 2021C03067).

Conflicts of interest/Competing interests The authors declare that they have no conflict of interest.

Availability of data and material The datasets generated during and analyzed during the current study are available from the corresponding author on reasonable request.

Code availability Not applicable 
Authors' contributions All authors contributed to the study conception and design and had an essential part in caring for the patients whose data was used in this manuscript. Data collection and analysis were performed by Jian Zheng, Buyi Zhang, Zhaoxu Huang, Danchan Lu and Chongran Sun. Additional datasets were provided by Hui Ling, Zhangqi Dou, Jiawei Wu, and Taian Jin. The first draft of the manuscript was written by Jian Zheng and Buyi Zhang, and all authors commented on previous versions of the manuscript. All authors read and approved the final manuscript.

Ethical approval Inclusion of patients into this analysis is approved by a local research ethics board.

Consent to participate Informed consent was obtained from all individual participants included in the study.

Consent for publication Patients signed informed consent regarding publishing their data.

\section{References}

1. Korfel A, Thiel E, Martus P, Möhle R, Griesinger F, Rauch M, Röth A, Hertenstein B, Fischer T, Hundsberger T, Mergenthaler HG, Junghanß C, Birnbaum T, Fischer L, Jahnke K, Herrlinger U, Roth P, Bamberg M, Pietsch T, Weller M (2015) Randomized phase III study of whole-brain radiotherapy for primary CNS lymphoma. Neurology 84:1242-1248.

2. Zhao D, Qian L, Shen J, Liu X, Mei K, Cen J, Wang Y, Li C, Ma Y (2014) Combined treatment of rituximab, idarubicin, dexamethasone, cytarabine, methotrexate with radiotherapy for primary central nervous system lymphoma. J Cell Mol Med 18:1081-1086.

3. Lin YZ, Huang MJ, Wang F, Xu DK, Gao Q, Zang WD, Guo FY, Li ZH (2020) Primary large B-cell lymphoma involving the cerebellopontine angle: a case report. Int J Clin Exp Pathol 13: 2612-2614.

4. Shin SC, Chung YG, Shin IY, Lee HG (2007) Primary Central Nervous System Lymphoma Presenting as Cerebellopontine Angle Lesion: A Case Report. J Korean Brain Tumor Soc 6:26-30.

5. Kommu V, Rachanakehra, Murthy S, Mallavarapu K, Sudhir R (2019) Primary central nervous lymphoma of cerebellopontine angle germinal center type: Report of a rare case. International Journal of Neurooncology 2:131.

6. Berrocal-Izquierdo N, Muoz F, Bosch J, Molet J (2018) Primary central nervous system lymphoma mimicking cerebellopontine angle tumour. Neurología 33:614-616.

7. Yan CR, Kong XY, Yang LS, Ma WB (2016) An uncommon case of lymphoplasmacytic lymphoma in cerebellopontine angle region: Case report with a literature review. Medicine (Baltimore) 95:e4627.

8. Danchaivijitr N, Hesselink JR, Aryan HE, Herndier B (2004) Cerebello-Pontine angle (CPA) lymphoma with perineural extension into the middle fossa: case report. Surg Neurol 62:80-85.

9. Nishimura T, Uchida Y, Fukuoka M, Ono Y, Kurisaka M, Mori K (1998) Cerebellopontine angle lymphoma: a case report and review of the literature. Surg Neurol 50:480-486.

10. Hill N, Little B, Vasan N, Giles M (2000) Cerebellopontine angle lymphoma presenting as chronic mastoiditis. J Laryngol Otol 114:618-620.

11. Yang PJ, Seeger JF, Carmody RF, Mehta BA (1987) Cerebellopontine angle lymphoma. AJNR Am J Neuroradiol 8:368-369.

12. Wang YT, Su HH, Hou Y, Chu ST, Lai PH, Tseng HH, Lin SJ, Chou YW (2007) Diffuse large B-cell lymphoma of the cerebellopontine angle in a patient with sudden hearing loss and facial palsy. J Chin Med Assoc 70:294- 
297.

13. Bonneville F, Savatovsky J, Chiras J (2007) Imaging of cerebellopontine angle lesions: an update. Part 2: intraaxial lesions, skull base lesions that may invade the CPA region, and non-enhancing extra-axial lesions. Eur Radiol 17:2908-2920.

14. Jaiswal AK, Mahapatra AK, Sharma MC (2004) Primary central nervous lymphoma presenting as bilateral cerebellopontine angle lesions: a rare case report. J Clin Neurosci 11:328-331.

15. Wen CY, Huang PH, Chang CJ, Hsieh CT (2015) Primary cerebellopontine angle lymphoma. Kaohsiung J Med Sci 31:55-56.

16. Garth RJ, Coddington R, Brightwell AP (1993) Primary cerebral lymphoma presenting with bilateral cerebellopontine angle lesions. J Laryngol Otol 107:937-939.

17. lerokomos A, Goin DW (1985) Primary CNS lymphoma in the cerebellopontine angle. Report of a case. Arch Otolaryngol 111:50-52.

18. Itoh T, Shimizu M, Kitami K, Kamata K, Mitsumori K, Fujita M, Ohnishi A, Nagashima K (2001) Primary extranodal marginal zone B-cell lymphoma of the mucosa-associated lymphoid tissue type in the CNS. Neuropathology 21:174-180.

19. Berciano J, Jiménez C, Figols J, Ferreres JC, Combarros O, Arjona R, Pascual J (1994) Primary leptomeningeal lymphoma presenting as cerebellopontine angle lesion. Neuroradiology 36:369-371.

20. Angeli SI, Brackmann DE, Xenellis JE, Poletti BJ, Carberry JN, Hitselberger WE (1998) Primary lymphoma of the internal auditory canal. Case report and review of the literature. Ann Otol Rhinol Laryngol 107:17-21.

21. Kariya S, Nishizaki K, Aoji K, Akagi H (1998) Primary malignant lymphoma in the cerebellopontine angle. J Laryngol Otol 112:476-479.

22. Taskin M, Wahl SJ, Amatulle P (1997) Primary peripheral T-cell lymphoma of the acoustic nerve. Otolaryngol Head Neck Surg 116:674-677.

23. Shuangshoti S (1995) Solitary primary lymphoma of the cerebellopontine angle: case report. Neurosurgery 36:595-598.

24. Seevaratnam V, Li Y, Lee SLK, Olsson G (2018) Primary central nervous system lymphoma at the cerebellopontine angle mimicking a trigeminal schwannoma: A unique case report and literature review. J Clin Neurosci 52:115-119.

25. Phang I, Craig-Mcquaide A, Kinch K, Taylor W (2018) Burkitt's neurolymphomatosis of the trigeminal nerve. BMJ Case Rep. https://doi.org/10.1136/bcr-2018-225958

26. Cederberg D, Marklund N, Nittby Redebrandt H (2020) Extreme intracranial pressure elevation $>90 \mathrm{mmHg}$ in an awake patient with primary CNS lymphoma-case report. Acta Neurochir (Wien) 162:1819-1823.

27. Mori Y, Yamamoto K, Ohno A, Fukunaga M, Nishikawa A (2019) Primary Central Nervous System Lymphoma with Peripheral Nerve Involvement: Case Report. Cureus 11:e5675.

28. Mielczarek M, Kubica A, Piotr Zieliński, Szylberg, M, Harat, M (2020) Primary central nervous lymphoma at the cerebellopontine angle: A case report. Interdiplinary Neurosurgery: Advanced Techniques and Case Management. https://doi.org/10.1016/j.inat.2020.100724

29. Socorro L, Briongos-Figuero, Tamara, Gómez-Traveso, José Luis, Pérez-Castrillon (2015) T-cell primary leptomeningeal lymphoma in cerebellopontine angle. BMJ Case Rep. https://doi.org/10.1136/bcr-2014208602 
30. Enam SA, Ali R (2011) B-cell lymphoma of the brainstem with central neurogenic hyperventilation. J Pak Med Assoc 61:925-927.

31. Han CH, Batchelor TT (2017) Diagnosis and management of primary central nervous system lymphoma. Cancer 123:4314-4324.

32. Batchelor, T (2006) Primary CNS lymphoma. Journal of Clinical Oncology Official Journal of the American Society of Clinical Oncology 24:1281-1288.

33. Koeller KK, Smirniotopoulos JG, Jones RV (1997) Primary central nervous system lymphoma: radiologicpathologic correlation. Radiographics 17:1497-1526.

34. Ta JH, Xu H (2013) Cerebellopontine angle lymphoma. Otol Neurotol 34:e123-124.

35. Calzada AP, Go JL, Tschirhart DL, Brackmann DE, Schwartz MS (2015) Cerebellopontine angle and intracanalicular masses mimicking vestibular schwannomas. Otol Neurotol 36:491-497.

36. Bonneville F, Sarrazin JL, Marsot-Dupuch K, Iffenecker C, Cordoliani YS, Doyon D, Bonneville JF (2001) Unusual lesions of the cerebellopontine angle: a segmental approach. Radiographics 21:419-438.

37. Kendall B, Symon, L (1977) Investigation of patients presenting with cerebellopontine angle syndromes. Neuroradiology 13, 65-84.

38. Haldorsen IS, Krakenes J, Krossnes BK, Mella O, Espeland A (2009) CT and MR imaging features of primary central nervous system lymphoma in Norway, 1989-2003. AJNR Am J Neuroradiol 30:744-751.

39. Bessell EM, Hoang-Xuan K, Ferreri AJ, Reni M (2007) Primary central nervous system lymphoma: biological aspects and controversies in management. Eur J Cancer 43:1141-1152.

40. Balmaceda C, Gaynor JJ, Sun M, Gluck JT, DeAngelis LM (1995) Leptomeningeal tumor in primary central nervous system lymphoma: recognition, significance, and implications. Ann Neurol 38:202-209.

\section{Figures}




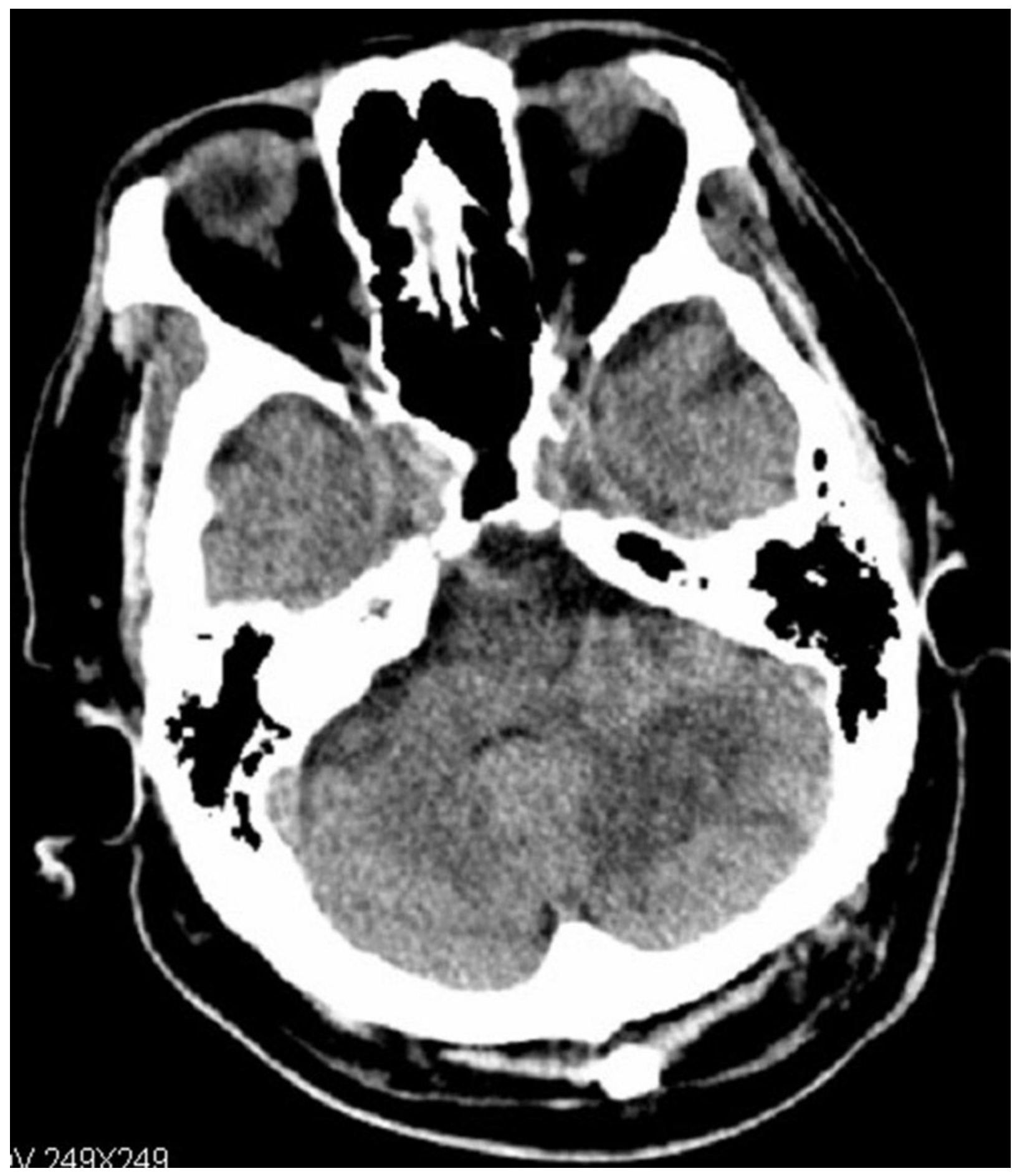

Figure 1

CT showed a slight hyperdense mass in the left CPA. 

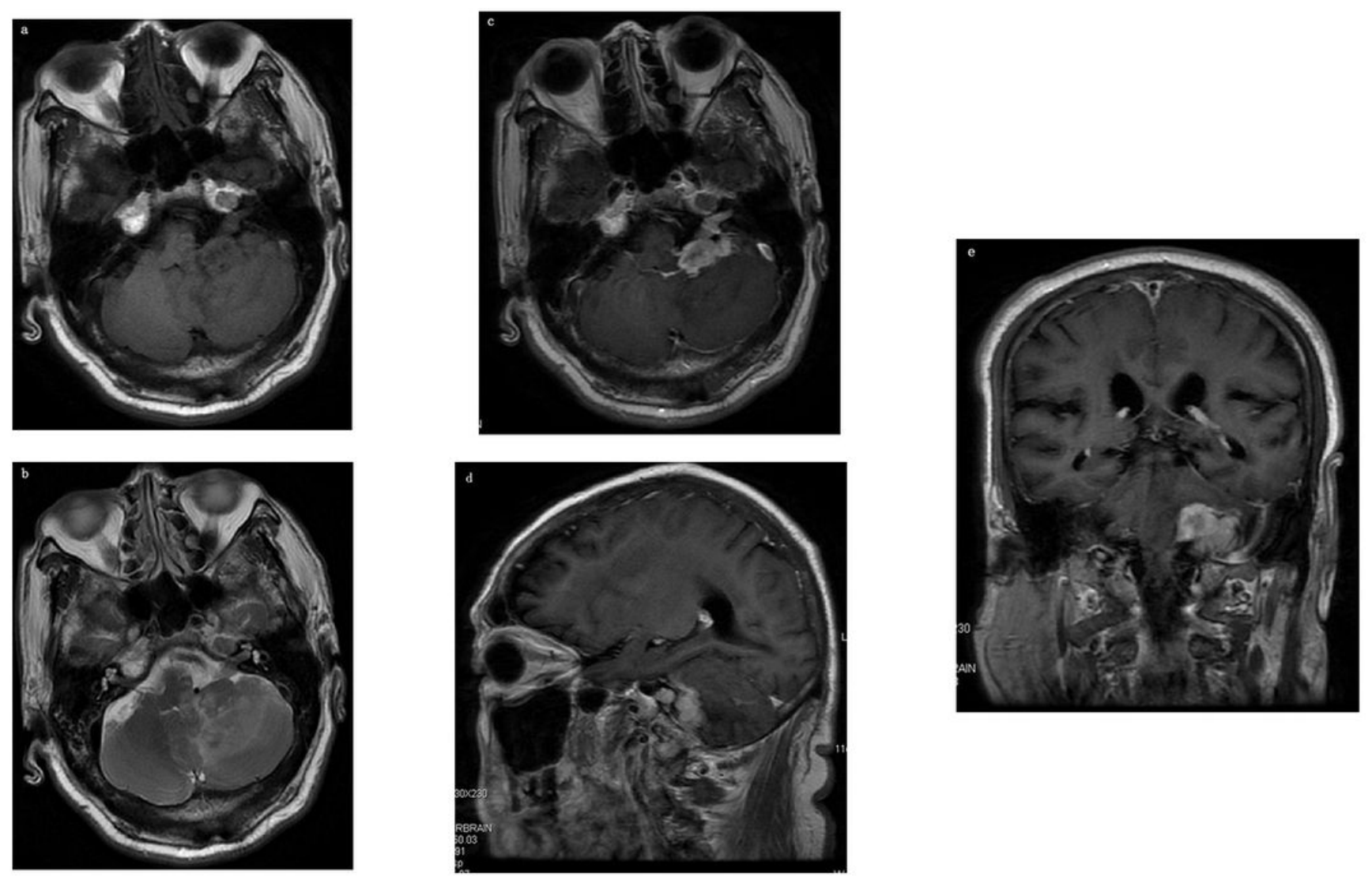

Figure 2

a An axial T1-weighted image showed an isointense mass. b An axial T2-weighted image showed an isointense mass, with perifocal edema. c A contrast-enhanced axial image revealed homogeneous enhancement of the lesion, extending into the left internal auditory canal. d A contrast-enhanced sagittal image revealed a wellenhanced mass lesion. e A contrast-enhanced coronal image revealed a well-enhanced mass lesion. 


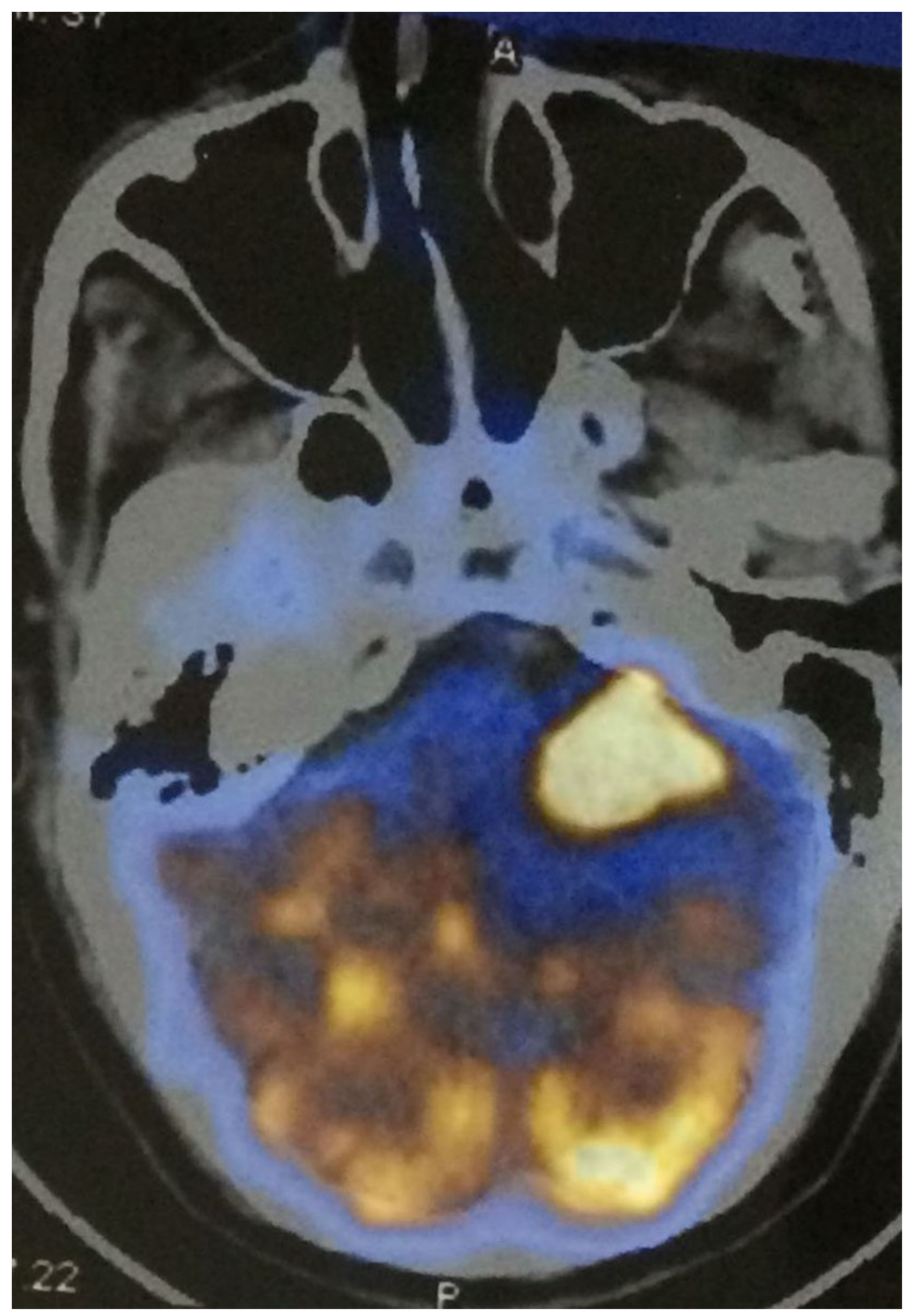

\section{Figure 3}

FDG-PET/CT examination showed an intensely hypermetabolic lesion in the left CPA. 

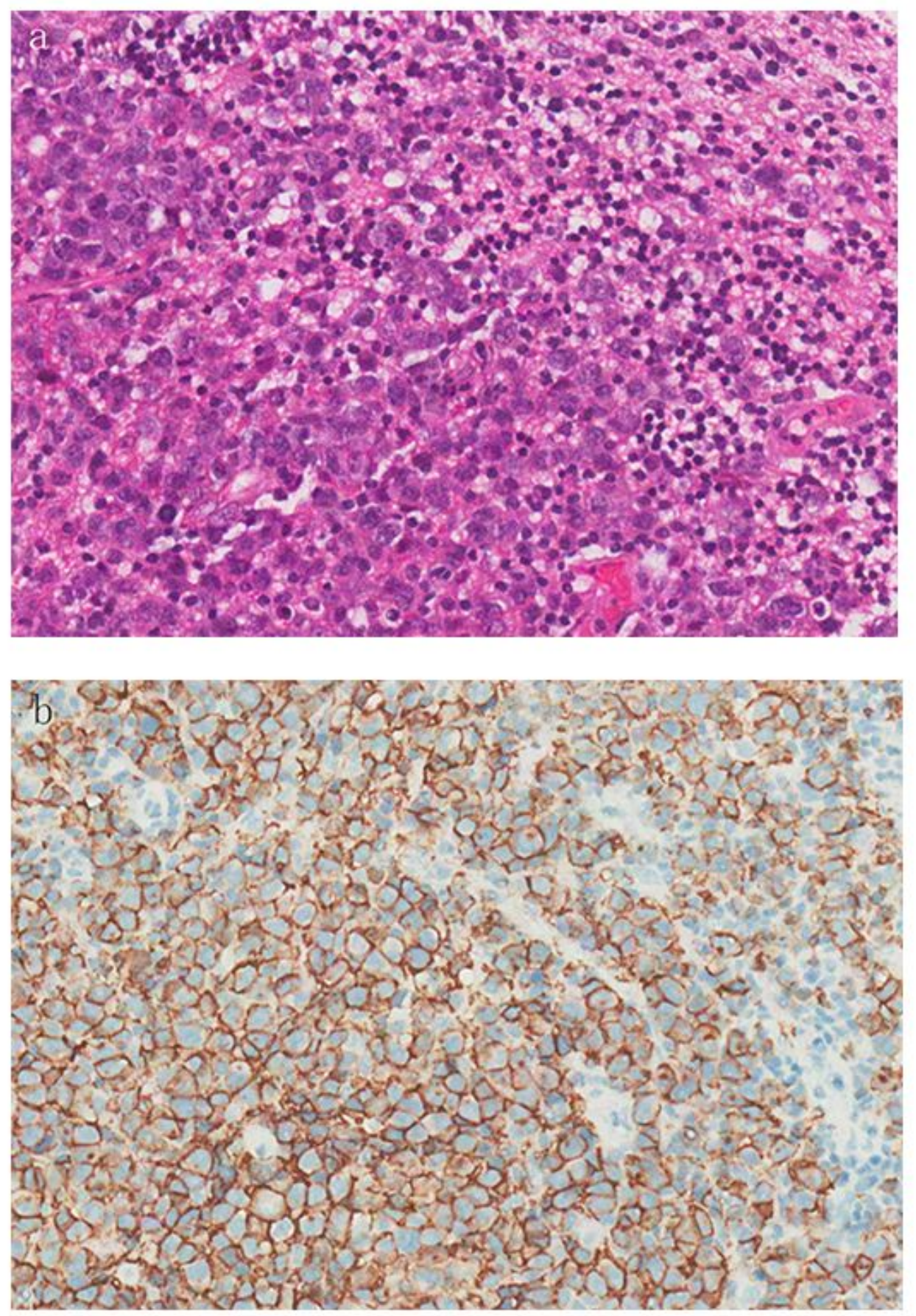

\section{Figure 4}

a Hematoxylin and eosin staining (magnification $\times 200$ ) showed diffuse infiltration of large anaplastic cells with irregular nuclei and scanty cytoplasm, with frequent mitoses and apoptosis. b CD-20 immunohistochemistry staining (magnification $\times 200$ ) demonstrating positivity. 